\title{
25th Anniversary Econometric Institute, Rotterdam, The Netherlands
}

On the occasion of the 25th anniversary of the Econometric Institute an International Symposium will be organized from 12 to 15 January 1982. Its main purpose is to bring together people from different parts of the world whose work is akin to the Econometric Institute's activities, for a discussion on recent developments in econometrics and related fields.

So far, J. H. Drèze, J. Durbin, D. Kendrick, E. Malinvaud, M. J. D. Powell and $H$. Theil have accepted the invitation to deliver a lecture.

General information is available from the Symposium secretary, Drs. B. S. van der Laan, Econometric Institute, Erasmus University, P.O. Box 1738, 3000 DR Rotterdam, The Netherlands. Telephone 010-525511.

\section{International Symposium on Mathematical Programming Bonn, West Germany, 1982}

The International Symposium on Mathematical Programming is the triennial scientific meeting of the Mathematical Programming Society. The XI. Symposium will be held at the University of Bonn from 23 to 27 August 1982. It will be organized by the Institut für Ökonometrie und Operations Research and the Sonderforschungsbereich 21 (DFG) of the Rheinische Friedrich-WilhelmsUniversität Bonn.

Papers on all theoretical, computational and applied aspects of mathematical programming are welcome; the presentation of very recent results is encouraged. Full information, including pre-registration forms, may be obtained from Math. Progr. Secretariat, c/o Institut für Operations Research, Nassestrasse 2, D-5300 Bonn 1, West Germany. (Telephone: (0228) 739203, Telex: 886657 UNIBO D). Forms should if possible be returned by 1 October 1981 . 